\title{
Limitations in identifying the equilibrium-line altitude from the optical remote-sensing derived snowline in the Tien Shan, China
}

\author{
WU Yuwei, ${ }^{1,2}$ HE Jianqiao, ${ }^{1}$ GUO Zhongming, ${ }^{1,2}$ CHEN Anan ${ }^{1,2}$ \\ ${ }^{1}$ State Key Laboratory of Cryospheric Sciences, Cold and Arid Regions Environmental and Engineering Research Institute, \\ Chinese Academy of Sciences, Lanzhou, China \\ E-mail: htwyw@lzb.ac.cn \\ ${ }^{2}$ Graduate University of Chinese Academy of Sciences, Beijing, China
}

\begin{abstract}
Optical remote-sensing derived end-of-summer snowline altitude (SLA) has long been employed on glaciers as an indicator of the equilibrium-line altitude (ELA). In the Tien Shan, northwest China, both accumulation and ablation of glaciers occur mainly in the warm season, making it difficult to obtain the representative snowline (highest snowline) in the area. The high spatio-temporal resolution of $\mathrm{HJ}-1$ satellite images enables the highest snowline to be acquired. In this paper, we compare image-derived SLA and measured in situ ELA for two adjacent glaciers in the Tien Shan over the period 2009-10. Results indicate that (1) in 2009, there was a substantial difference between SLA and ELA on one glacier, suggesting inconsistent applicability in using SLA to identify ELA over a large area; and (2) in 2010, an intense ablation year, the field-data-derived ELA surpassed the glacier peak. In this situation, there is no theoretical relationship between SLA and ELA, and the image-derived snowline actually indicates the boundary between ice and firn from previous years. In summary, errors will arise from the discrepancies between individual glaciers and from intensive ablation when using SLA to identify ELA over a large area.
\end{abstract}

KEYWORDS: mountain glaciers, remote sensing

\section{INTRODUCTION}

The equilibrium line is the theoretical line on a glacier where annual mass accumulation equals annual mass loss. Glacier behaviour such as advance or retreat is controlled by variations in the equilibrium line (Wang and others, 2010). Variations in the glacier equilibrium-line altitude (ELA) are more sensitive to climate change than are variations in glacier length or area, and thus have been studied to understand the relationships between glacier variations and climate regime (e.g. Kuhn, 1989; Ohmura and others, 1992; Fountain and others, 1999; Benn and Lehmkuhl, 2000; Wang and others, 2010; Rabatel and others, 2013). To date, because it is difficult to access glaciers to conduct fieldwork, the ELAs of only a few glaciers have been studied using instrumental data (Kaser and others, 2006; WGMS, 2012). In recent years, many studies have used remote-sensing data to analyse variations in glacier area and length over more extensive regions including the Tien Shan, northwest China (e.g. Haeberli, 2004; Aizen and others, 2007; Bolch, 2007; Paul and others, 2007; Kutuzov and Shahgedanova, 2009; Racoviteanu and others, 2009; Narama and others, 2010; Bolch and others, 2012; Yao and others, 2012; Wang and others, 2013). Remote-sensing techniques provide a unique opportunity to determine ELA over a large area.

Snowfall supplies glaciers with mass, so snow-covered areas should indicate where accumulation has occurred. Early studies hypothesized that the snowline from optical images in the late ablation season could be used as an indicator of the ELA (LaChapelle, 1962; Lliboutry, 1965). This theory has been applied to the Himalaya, western North America, the Patagonia icefields, the European Alps and to tropical glaciers to estimate glacier ELA, or even mass balance (e.g. Kulkarni, 1992; Chinn, 1995; Lamont and others, 1999; Clare and others, 2002; Rabatel and others, 2005, 2008, 2012; Barcaza and others, 2009; Shea and others, 2013). In these areas, aerial photographs, Thematic Mapper (TM)/Enhanced TM (ETM) or Moderate Resolution Imaging Spectroradiometer (MODIS) satellite and other optical remote-sensing images have been used to determine the snowline at the end of the ablation season. In the Tien Shan, however, both accumulation and ablation occur mainly in the warm season, making it difficult to obtain the representative (i.e. highest) snowline due to a scarcity of remote-sensing images with high temporal and spatial resolution. The Environment Satellite 1 (also known as the HJ-1 satellite) launched in 2008 revisits a given point on the Earth's surface every 48 hours (Bai, 2009), and acquires multispectral images with a spatial resolution of $30 \mathrm{~m}$, making it possible to image the highest snowline. In this paper, we use HJ-1 satellite images with a high temporal resolution to derive snowline altitude (SLA). We then compare the highest image-derived SLA with the annual ELA from in situ measurements during the 2009 (most positive mass-balance year since 1990) and 2010 (most negative mass-balance year since 1990) ablation seasons at Ürümqi glacier No. 1, and assess the limitations on the use of SLA as an indicator of ELA. Unlike previous studies (Lamont and others, 1999; Rabatel and others, 2005, 2008, 2012; Shea and others, 2013), which focused on the statistical correlations between SLA and ELA over long periods, the present study focuses on the differences between SLA and ELA for a specific set of representative years at Ürümqi glacier No. 1, thereby aiming to understand the differences between SLA and ELA in the Tien Shan.

\section{STUDY AREA}

Ürümqi glacier No. 1, lying on the north slope of Tianger mountain $\left(43^{\circ} 06^{\prime} \mathrm{N}, 86^{\circ} 49^{\prime} \mathrm{E}\right)$, Tien Shan, consists of two cirque valley glaciers, an east branch and a west branch 


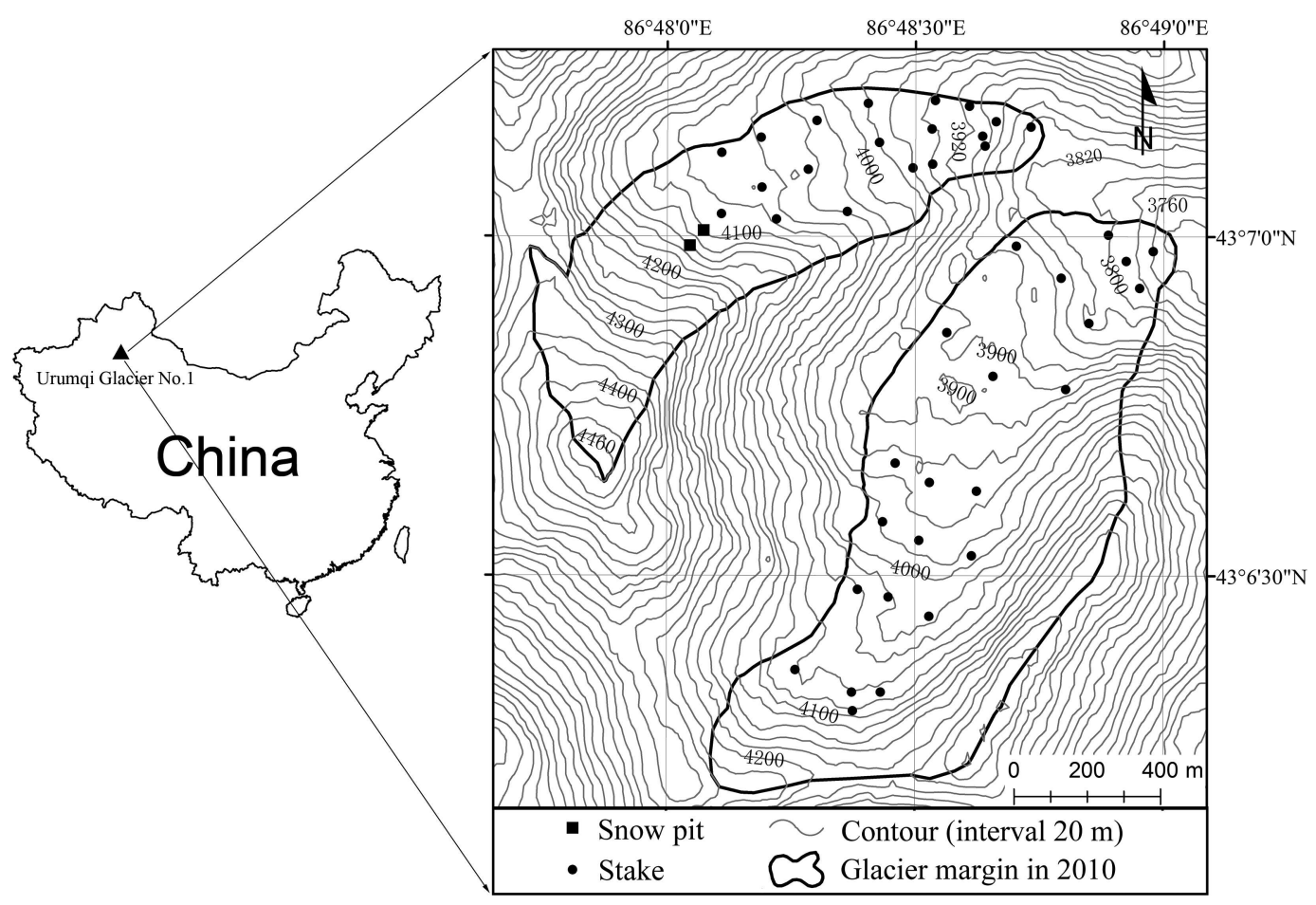

Fig. 1. Location of Ürümqi glacier No. 1 in central Tien Shan, northwest China. The bold black lines indicate the outlines of the two glaciers.

(Fig. 1). In 2006, the east glacier covered an area of $1.086 \mathrm{~km}^{2}$, with a maximum elevation of $4267 \mathrm{~m}$ and terminus at an altitude of $3743 \mathrm{~m}$, while the west glacier covered $0.591 \mathrm{~km}^{2}$, with a maximum elevation of $4484 \mathrm{~m}$ and terminus at $3845 \mathrm{~m}$ (WGMS, 2012). Both accumulation and melt of the glacier occur mainly in the warm season, when the glacier develops superimposed ice typical of a continental glacier. Ürümqi glacier No. 1 is representative of continental glaciers in central Asia and is one of the ten reference glaciers selected for the World Glacier Monitoring Service (WGMS) monitoring network (WGMS, 2012). Observations of Ürümqi glacier No. 1 date from 1959 (Li and others, 2003) and constitute the longest glacier massbalance record in China. Much glaciological research has been conducted here, including mass balance, variation in ELA, variation in glacier length/area/volume, and the response of the glacier to climate change (e.g. Li, 2011; Wang and others, 2011, 2014). In this paper, the ELA from in situ measurements is compared with the SLA derived from remote-sensing images.

\section{MATERIALS AND METHODS}

In 2009, 41 stakes were drilled into the glacier from the terminus to the head over the east and west branches, covering different altitude zones, and with gaps in elevation generally no more than $50 \mathrm{~m}$. Two snow pits were also dug in the west branch accumulation zone (Fig. 1). The distribution of stakes was similar in 2010. The annual ELA calculation includes the following steps. First, variations in water equivalent accumulation (or ablation) were obtained by measuring the densities of ice and snow at stake points and snow pits, and by measuring the stake height changes from the end of one hydrological year $(\sim 31$ August in our study area) to the end of the next hydrological year for calculations of point mass balance. Second, using the areaaltitude distribution, the point values were extrapolated over the glacier (Østrem and Brugman, 1991). Third, the ELA was calculated by determining the average contour of the zero equilibrium line (Paterson, 1994; Fountain and others, 1999; Benn and Lehmkuhl, 2000). Thus, the precision of ELA estimates depends on mass-balance measurement. Comparisons between the glaciological and geodetic mass balance at Ürümqi glacier No. 1 over 1981-2009 (Fig. 1) indicated that the glaciological method mass-balance data are of high quality (Wang and others, 2014), so there is no need to calibrate the ELA data in this study.

The nearest weather station to Ürümqi glacier No. 1 is Daxigou station (3539 ma.s.l.), which is situated $\sim 2.0 \mathrm{~km}$ from the end of the glacier. The daily temperature and precipitation at Daxigou station from July to September in 2009 and 2010 are used in the present study, as supplied by the Xinjiang Meteorological Information Center.

The remote-sensing images are acquired by CCD cameras on the $\mathrm{HJ}-1$ satellite. The $\mathrm{HJ}-1$ satellite, consisting of small twin satellites $(\mathrm{HJ}-1 \mathrm{~A}$ and $\mathrm{HJ}-1 \mathrm{~B})$, has two multispectral visible light cameras with wide coverage (CCD camera), and the width of a joint image is $710 \mathrm{~km}$ when the two CCD cameras operate in parallel view mode. The twin satellites revisit a given point on the Earth's surface every 48 hours, and create multispectral images with a spatial resolution of $30 \mathrm{~m}$. The spectral range is $0.43-0.9 \mu \mathrm{m}$ and is divided into four bands: $0.43-0.52,0.52-0.60,0.63-0.69$ and $0.76-0.90 \mu \mathrm{m}$ (Bai, 2009). In the present study, we use a set of HJ-1 images for the period July to September in 2009 and 2010, as obtained from the China Centre for Resources Satellite Data and Application (http://www.cresda.com). The July-September period spans the entire late ablation season. From July to September 2009, there are image records for 61 days out of a total of 92, but most of the images were not used because they are affected by cloud shadows or because the surface is completely snow-covered, and only 13 usable images are retained (Table 1). In 2010, 19 suitable images out of a total of 66 are used (Table 1). 
Landsat TM and ETM+ data have been widely used for snowline identification because of the obvious reflectance differences between ice and firn or snow (Williams and others, 1991; Klein and Isacks, 1999; Bindschadler and others, 2001; Pelto, 2011; Rabatel and others, 2013). Using visual interpretation, the manual snowlines from TM/ETM+ images are therefore used to validate the manual snowlines derived from HJ-1 images. The results show high consistency between the snowlines extracted from the fourth spectral band of the HJ satellite and from TM/ETM+ images (combination of spectral bands 5, 4, 3). Figure 2 provides an example to show that using $\mathrm{HJ}-1$ data to extract SLA is the same as using Landsat data on 4 August 2010. Therefore, the fourth spectral band $\mathrm{HJ}$ satellite images are used to determine variations of the snowline on Ürümqi glacier No. 1. In the present study, the SLA is calculated by superimposing the HJ-1 image-derived snowlines on elevation data (described below), using ArcMap software (http:// www.esri.com/software/arcgis/arcgis-for-desktop). Since ELA is the average altitude of the equilibrium line, the SLA is also the average value of the corresponding snowline elevation. We have considered that the scarcity of stakes on the steep areas of the glacier may influence the value of the ELA. Thus, we did not take the snowline of the steep areas of the glacier into account for this study. ELA is based on stake mass balance along the glacier; both ends of the manual snowline are also controlled by the stakes' positions on two sides of the glacier.

The elevation dataset is the Global Digital Elevation Model (GDEM, version 2), obtained from the Advanced Spaceborne Thermal Emission and Reflection Radiometer (ASTER). It has $17 \mathrm{~m}$ vertical accuracy $(P<0.05)$ (Tachikawa and others, 2011), and a horizontal resolution of $26.5 \mathrm{~m}$ in the study area. Previous studies have suggested that the average thinning of Ürümqi glacier No. 1 was $\sim 3.1 \mathrm{~m}$ during the period 2001-06 (Wang and others, 2011). Because the GDEM is obtained after December 1999, there was no need to undertake altitudinal correction of the SLA since the GDEM accuracy is an order of magnitude larger than the change in surface height.

The uncertainty was estimated for each SLA, and there are two main sources of error. First, a vertical error is caused by the horizontal error in the location of the snowline. Due
Table 1. SLAs derived from HJ-1 satellite images, and their uncertainty

\begin{tabular}{ccc}
\hline Date & West glacier SLA & East glacier SLA \\
$\mathrm{m}$ & $\mathrm{m}$
\end{tabular}

\begin{tabular}{|c|c|c|}
\hline 12 Jul 2009 & $3933 \pm 24$ & $3832 \pm 27$ \\
\hline $18 \mathrm{Jul} 2009$ & $3849 \pm 27$ & $3800 \pm 23$ \\
\hline 20 Jul 2009 & $3937 \pm 25$ & $3842 \pm 27$ \\
\hline 24 Jul 2009 & $3973 \pm 27$ & $3892 \pm 22$ \\
\hline 2 Aug 2009 & $3990 \pm 25$ & $3915 \pm 24$ \\
\hline 10 Aug 2009 & $3951 \pm 25$ & $3858 \pm 24$ \\
\hline 13 Aug 2009 & $3845 \pm 17$ & $3776 \pm 27$ \\
\hline 26 Aug 2009 & $3934 \pm 25$ & $3812 \pm 25$ \\
\hline 30 Aug 2009 & $3845 \pm 17$ & $3782 \pm 28$ \\
\hline 1 Sep 2009 & $3865 \pm 33$ & $3828 \pm 27$ \\
\hline 12 Sep 2009 & $3936 \pm 24$ & $3841 \pm 27$ \\
\hline 16 Sep 2009 & $3950 \pm 25$ & $3883 \pm 24$ \\
\hline 22 Sep 2009 & $3846 \pm 31$ & $3772 \pm 28$ \\
\hline 31 Aug 2010 & $3880 \pm 33$ & $3841 \pm 28$ \\
\hline 6 Sep 2010 & $3909 \pm 29$ & $3877 \pm 25$ \\
\hline 7 Sep 2010 & $3962 \pm 26$ & $3897 \pm 24$ \\
\hline 9 Sep 2010 & $4051 \pm 23$ & $3971 \pm 24$ \\
\hline 10 Sep 2010 & $4076 \pm 24$ & $4070 \pm 27$ \\
\hline 19 Sep 2010 & $3961 \pm 27$ & $3829 \pm 26$ \\
\hline 2 Jul 2010 & $3985 \pm 25$ & $3896 \pm 25$ \\
\hline 11 Jul 2010 & $3993 \pm 25$ & $3894 \pm 25$ \\
\hline 15 Jul 2010 & $3964 \pm 26$ & $3896 \pm 25$ \\
\hline 2 Aug 2010 & $4062 \pm 23$ & $4040 \pm 25$ \\
\hline 3 Aug 2010 & $4064 \pm 23$ & $4041 \pm 25$ \\
\hline 4 Aug 2010 & $4068 \pm 23$ & $4047 \pm 25$ \\
\hline 5 Aug 2010 & $4072 \pm 25$ & $4055 \pm 30$ \\
\hline 9 Aug 2010 & $4071 \pm 24$ & $4063 \pm 29$ \\
\hline 11 Aug 2010 & $4075 \pm 26$ & $4062 \pm 27$ \\
\hline 12 Aug 2010 & $4076 \pm 26$ & $4069 \pm 27$ \\
\hline 13 Aug 2010 & $4082 \pm 25$ & $4077 \pm 27$ \\
\hline 14 Aug 2010 & $4086 \pm 25$ & $4115 \pm 30$ \\
\hline 23 Aug 2010 & $4084 \pm 26$ & $4079 \pm 29$ \\
\hline
\end{tabular}

to the obvious reflectance differences between ice and firn or snow (Bai and Ohata, 1989), the errors in location of the manual snowline will not exceed one pixel in remotesensing images; therefore, we defined one pixel size (i.e. $30 \mathrm{~m})$ as the horizontal error of the snowline. The vertical error associated with the horizontal error can be obtained by

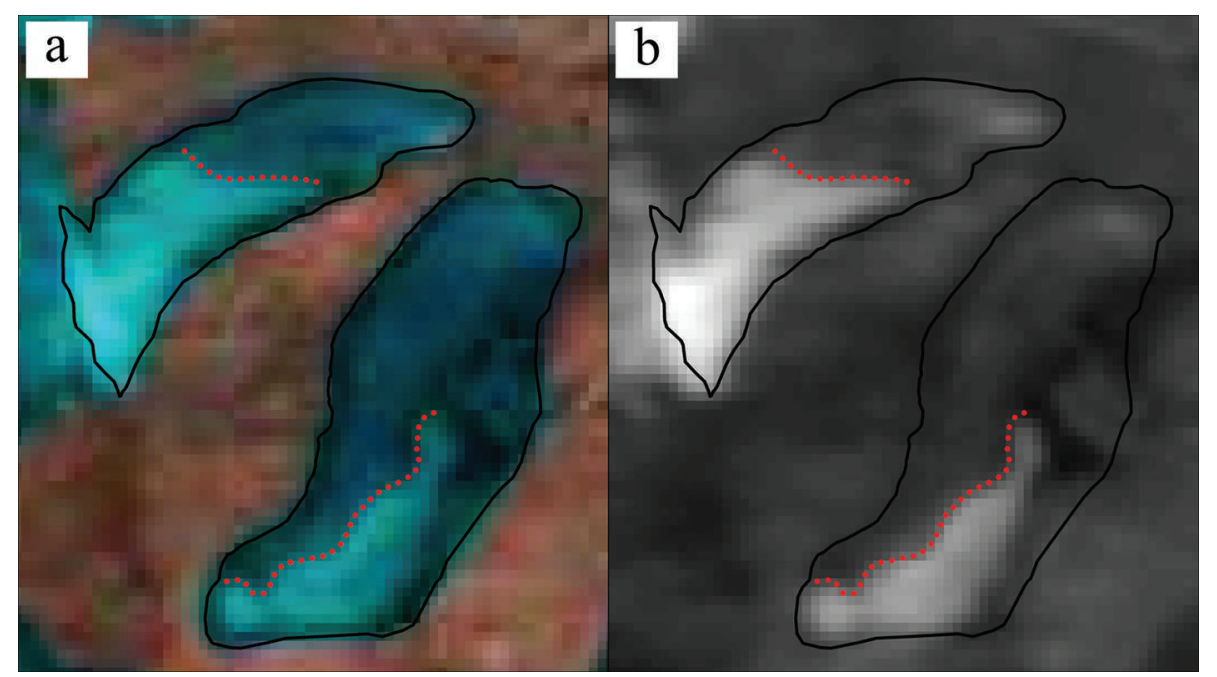

Fig. 2. Comparisons between snowlines (red dotted lines) at Ürümqi glacier No. 1 identified from (a) a TM image using reflectance integrated over bands 3-5, and (b) the HJ-1 satellite fourth band reflectance image on 4 August 2010. 


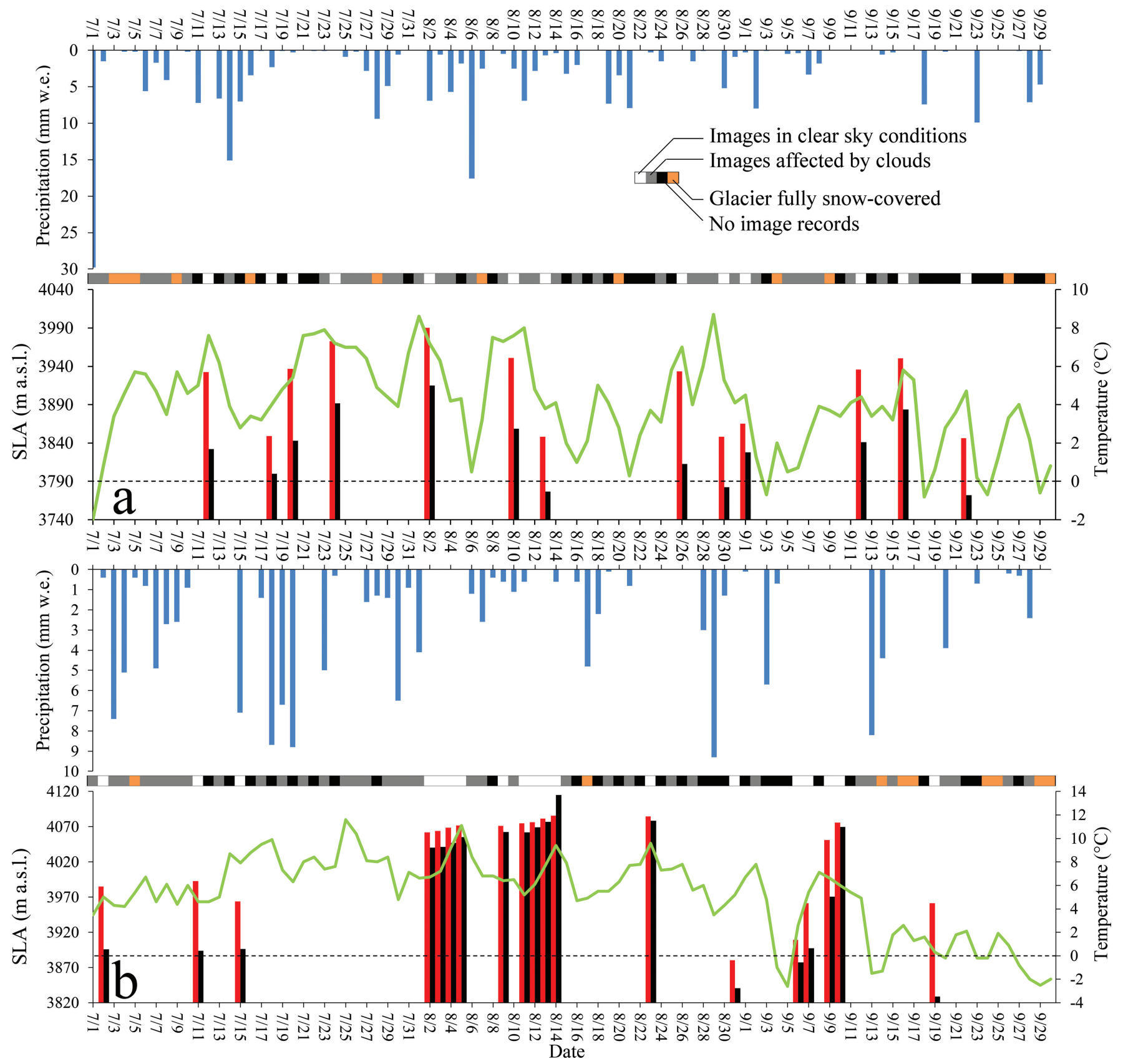

Fig. 3. Comparisons between the SLA of Ürümqi glacier No. 1, extracted from the HJ-1 satellite images, and the daily temperature (green line) and precipitation (blue bars) records at Daxigou station, for the periods (a) 1 July to 30 September 2009 and (b) 1 July to 30 September 2010 (horizontal axis date format is month/day). The SLA from the west branch is shown in red bars, while that from the east branch is shown in black bars. The colourful belts in the middle denote the influences of external factors on the HJ-1 satellite images: white blocks indicate clear-sky conditions; grey blocks indicate that the images are affected by clouds (including thick clouds, thin clouds, or fog); orange blocks indicate that the glacier is fully covered by snow; and black blocks indicate no image records (except for 14 July 2009 , when the image is so deformed that registration cannot be done properly).

multiplying the pixel size by the slope of the glacier in the vicinity of the SLA. The second source of error is the vertical accuracy of the GDEM, which was $17 \mathrm{~m}(P<0.05)$. The uncertainty in SLA will not exceed the sum of these two independent errors, and the calculated errors range from \pm 17 to $\pm 33 \mathrm{~m}$ (Table 1$)$.

\section{RESULTS}

The SLAs were extracted from the available HJ satellite images (Table 1). It is well known that snowfall will lower, while an increase in temperature will raise, the SLA of a glacier. Transient SLAs derived from individual images will therefore rise or fall depending on temperature and precipitation (Fig. 3).

Figure 3 shows that for periods between precipitation events, the relationship between temperature and SLA is clear, i.e. increased temperature results in an increased SLA. Therefore, precipitation has minimal impact on the extracted maximum SLA for a given temperature, and we can examine the relationship between temperature and SLA independent of precipitation events. For a given temperature $a$, the corresponding SLAs may differ because they are affected by specific snowfall and weather conditions. We extracted the maximum value of all the SLAs whose corresponding temperature is $\pm a$ and defined it as $\operatorname{SLA}_{a}$ 
(the relative highest SLA for temperature a). This is easy to extend when a temperature $b$ is greater (less) than $a: \operatorname{SLA}_{b}$ (the relative highest SLA for temperature $b$ ) will be no less (no greater) than $\mathrm{SLA}_{a}$. We filtered all the image-derived SLAs according to this rule, and then obtained 'the relative highest $\mathrm{SLA}^{\prime}$ as a function of temperature in 2009-10 (Fig. 4). We omitted the SLA on 19 September 2010, because the temperature that day was too low $\left(0.3^{\circ} \mathrm{C}\right)$ to influence the SLA given that the meteorological station is $\sim 200 \mathrm{~m}$ below the glacier terminus.

Comparisons between the daily mean temperature and the relative highest SLA (Fig. 4) indicate that the rate of increase of the SLA declines to near zero when it exceeds certain threshold values $\left(8.6^{\circ} \mathrm{C}\right.$ and $9.4^{\circ} \mathrm{C}$ for 2009 and 2010 respectively, both of which are the daily mean temperature of highest remote-image-derived SLA). Therefore, the highest image-derived SLA can be considered as the highest SLA of the corresponding years. We infer that temperature rises will initially increase the SLA, but then might have relatively less impact on the SLA. We now examine the temperature time series to identify the highest SLA for both years and glaciers, based on Figure 3. On 1 August 2009, the daily mean temperature was the second highest during the 2009 study period $\left(8.6^{\circ} \mathrm{C}\right)$, which contributed to the highest $\mathrm{HJ}$-image-derived SLA, $3915 \pm 24 \mathrm{~m}$ and $3990 \pm 25 \mathrm{~m}$ for the east and west glaciers, respectively (the SLA of 2 August is taken to be the same as that of 1 August, since the satellite passed over the glacier before the precipitation event that occurred on 2 August). The warmest day was 29 August $\left(8.7^{\circ} \mathrm{C}\right)$, but because of cloud shadowing we cannot directly obtain the SLA. We deduce from the temporal variation of the relative highest SLAs that the image-derived SLA on 1 August 2009 may represent the highest SLA in 2009. In 2010, the SLA on 14 August $\left(9.4^{\circ} \mathrm{C}\right)$ had the highest $\mathrm{HJ}$-image-derived SLA, with $4115 \pm 30 \mathrm{~m}$ and $4086 \pm 25 \mathrm{~m}$ elevations on the east and west glaciers, respectively. Only 5 out of 92 days (from July to September) had temperature higher than that of 14 August in 2010: 17 and 18 July $\left(9.5^{\circ} \mathrm{C}\right.$ and $9.9^{\circ} \mathrm{C}$, respectively; and there was a heavy snowfall on 15 July); 25 and 26 July $\left(11.6^{\circ} \mathrm{C}\right.$ and $10.4^{\circ} \mathrm{C}$, respectively; and there was a heavy snowfall on 23 July); and 5 August $\left(11.1^{\circ} \mathrm{C}\right.$, and the SLA was smaller than that of 14 August). A heavy snowfall will dramatically lower the SLA on those days with higher temperature. Consequently, there is very low probability that the corresponding SLAs were higher than the SLA on 14 August, and we infer that the SLA on 14 August represents the highest SLA in 2010.

In 2009, the differences between the deduced highest SLA $(3915 \pm 24 \mathrm{~m}$ and $3990 \pm 25 \mathrm{~m}$ for the east and west glaciers, respectively) and the measured ELA (3975 and $4010 \mathrm{~m}$ for the east and west glaciers, respectively) are $60 \pm 24 \mathrm{~m}$ and $20 \pm 25 \mathrm{~m}$, respectively. The west glacier SLA can be used to indicate the ELA; however, the difference for the east glacier is large for such a small glacier (the range in altitude is $524 \mathrm{~m}$ ).

The ELA in 2010 was higher than the mountain peak. The ELA of the east glacier was no less than $4267 \mathrm{~m}$, and that of the west glacier was no less than $4484 \mathrm{~m}$, so the deduced snowline elevations on the east and west glaciers were at least $152 \pm 30 \mathrm{~m}$ and $398 \pm 25 \mathrm{~m}$ lower respectively than their corresponding ELAs. If the ELA of one year exceeds the glacier peak, then there will be no accumulation area on the glacier that year, and the snowline is actually the lower
- Relative highest SLAs; east glacier

Other SLAs; east glacier

Relative highest SLAs; west glacier Other SLAs; west glacier

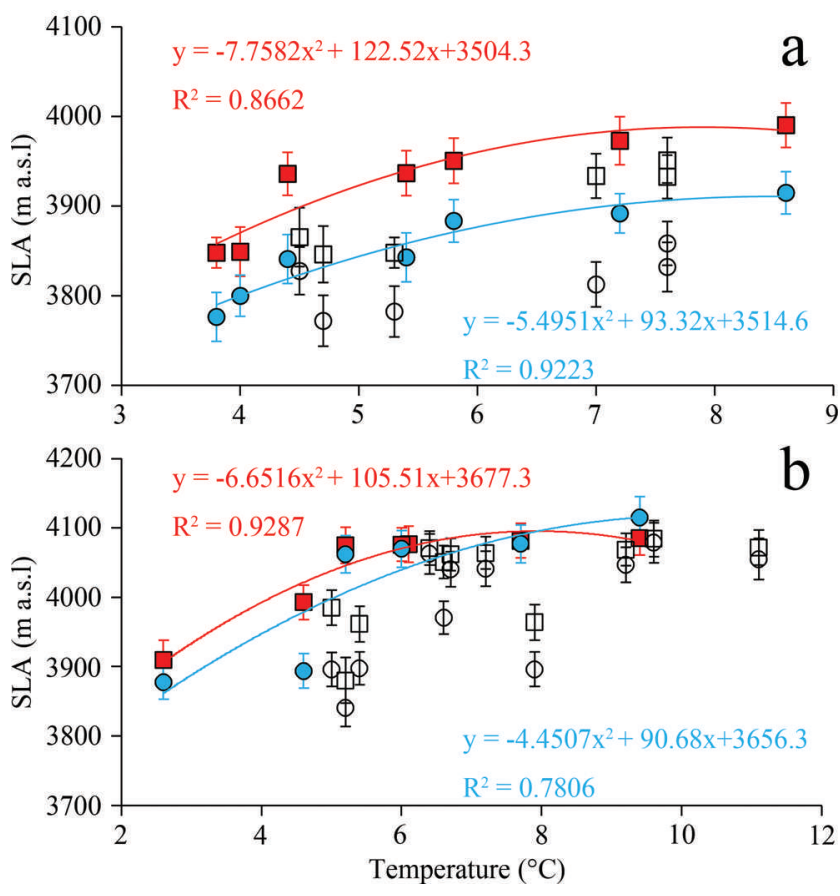

Fig. 4. Ürümqi glacier No. 1 SLA extracted from HJ-1 satellite images as a function of temperature in (a) 2009 and (b) 2010 over the east (circles) and west (squares) glaciers, and their corresponding quadratic regression lines. The relative highest SLAs are shown as solid red (east) and blue (west) symbols.

boundary of the accumulated firn of previous years. In this case, there is no theoretical relationship between SLA and ELA.

It was believed that the superimposed ice of the cold glacier would cause the SLA in the late ablation season to exceed the ELA (Lliboutry, 1998), but the estimated SLA is lower than the ELA in both 2009 and 2010. Consequently, the superimposed ice may have less impact on SLA as an indicator of ELA than the other limitations on Ürümqi glacier No. 1.

\section{DISCUSSIONS AND CONCLUSIONS}

In 2009, the highest SLA and the measured ELA were very close on the west glacier, as shown schematically by Figure 5a. However, large differences existed between SLA and ELA on the east glacier, which suggests that the applicability of the image-derived SLA for identifying ELA varies even for two adjacent glaciers in the Tien Shan. The topography of individual glaciers and their surroundings may be one of the reasons for this discrepancy (Hock and Holmgren, 1996, 2005; Hulth and others, 2013). Although we cannot determine the specific reasons for this difference, given the limits of the current data and the complexity of glacier ablation, this discrepancy is still real.

The 2010 image-derived highest snowline of Ürümqi glacier No. 1 indicates that optical remote-sensing images only distinguish snow (or firn) from ice (Williams and others, 1991; Parrot and others, 1993; Pope and Rees, 2014a,b), but cannot distinguish snowfall in the present year from that accumulated previously. This limitation will confuse the firn line from previous years with the snowline from the present 


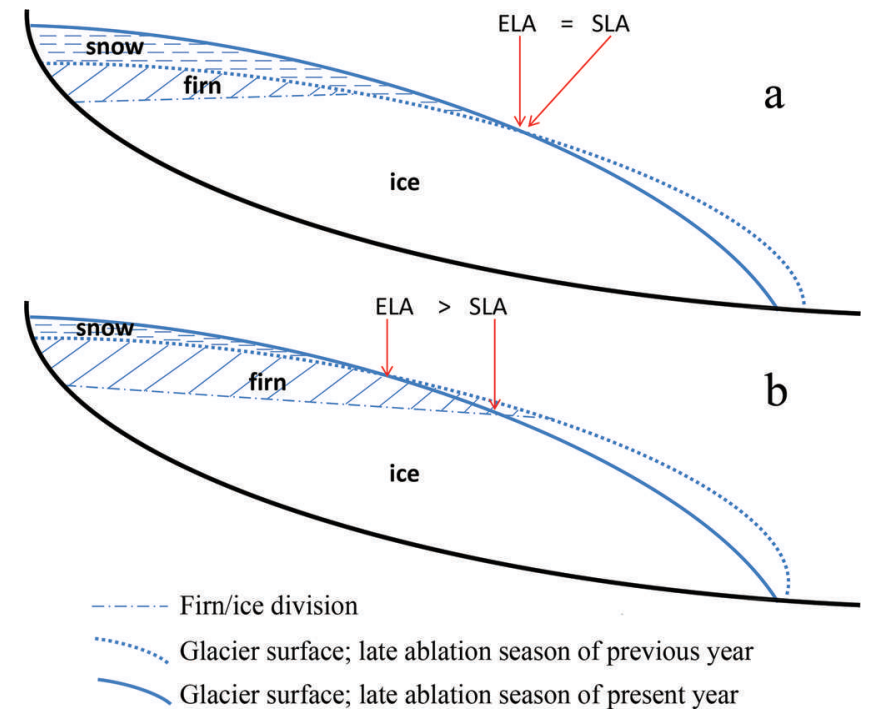

Fig. 5. Schematic diagram showing a lengthwise cross section of a mountain glacier (after Brown and others, 1999; De Ruyter de Wildt and others, 2002). The glacier surface in the late ablation season in the present mass-balance year (the last mass-balance year) is shown by blue solid (dotted) lines. The division between firn (blue hatching) and ice is shown by the blue dashed line. (a) When snow covers all the firn, ELA equals SLA. (b) When the mass balance is much more negative than in previous years, firn is exposed and ELA is larger than SLA.

year, while the equilibrium line should refer to the snowline from the present year's accumulated snow.

We present three scenarios, without considering glacier movement and superimposed ice, for Ürümqi glacier No. 1 (Fig. 5). The first scenario (Fig. 5a) often occurs in positive mass-balance years, when the present year's snow (or firn) layer can completely cover the firn portion from the previous year. In this situation, the equilibrium line and snowline extracted from remotely sensed images are the same line, and SLA equals ELA. The second scenario may occur in positive or negative mass-balance years (Fig. 5b), when ablation can reach the firn layer accumulated the previous year, so the image-deduced snowline is actually the lower boundary of the firn layer from the previous year. When the glaciers conform to either of these scenarios (i.e. when the difference between SLA and ELA is small), the correlations between SLA and ELA may succeed in passing the statistical significance test at a long timescale, or the absolute values of SLA and ELA will be approximate (e.g. the SLA and ELA of the west branch of Ürümqi glacier No. 1 in 2009). In these cases, the SLA can be an indicator of the ELA. The third scenario could be seen as a severe case of the second scenario: ELA exceeds the summit of the glacier, primarily occurring in the years with extremely negative mass balance. The glacier surface is identical to the ablation zone, which indicates that the image-derived snowline is the lower boundary of firn accumulated in previous years. In this scenario, there is no theoretical relationship between SLA and ELA. This situation has also been proposed previously (Brown and others, 1999; De Ruyter de Wildt and others, 2002), and is apparent for Ürümqi glacier No. 1 in 2010, as there was no snow from this year on the glacier surface and the firn from previous years was exposed everywhere.

Establishing a dataset of temporal and spatial ELAs from remote-sensing images is an attractive idea, and an understanding of the limitations of using SLA to indicate ELA is necessary. Engeset and Weydahl (1998) and Engeset and others (2002) proposed that the ELA could be derived by synthetic aperture radar (SAR) imagery; however, there has been considerable debate about this approach (Hall and others, 2000; Jaenicke and others, 2006; Casey and Kelly, 2010; Huang and others, 2013). In microwave remotely sensed imagery, the present year's accumulated snow lies on top of the old stratigraphy, so the equilibrium line may be obscured by old firn, since snow and firn look similar on SAR images (Hall and others, 2000; König and others, 2001). Our results reveal the same problem for optical remote-sensing images. Whether optical remote-sensing images can distinguish snow from firn is still a critical issue. In recent years, the ablation of glaciers has been accelerating in many parts of the world (Cogley, 2009; Jacob and others, 2012; Gardner and others, 2013). Highablation years, exemplified by Ürümqi glacier No. 1 in 2010, will likely impact other glaciers. The intensities of glacier ablation will also affect the applicability of using SLA to indicate ELA.

\section{ACKNOWLEDGEMENTS}

We thank the Tien Shan Glaciological Station for the source data, WGMS for shared ELA data, the contributors of remote-sensing images for their efforts in constructing the image database used in this study and the Xinjiang Meteorological Information Center for meteorological data. We also thank two anonymous reviewers for critical comments on the manuscript. This work was supported by the National Basic Research Program of China (2010CB951404), the Young Talents funding of the Cold and Arid Regions Environmental and Engineering Research Institute, Chinese Academy of Sciences (Y35111001), the 'Strategic Priority Research Program (B)' of the Chinese Academy of Sciences (XDB03030204), and the National Natural Science Foundation of China (41190084).

\section{REFERENCES}

Aizen VB, Kuzmichenok VA, Surazakov AB and Aizen EM (2007) Glacier changes in the Tien Shan as determined from topographic and remotely sensed data. Global Planet. Change, 56(3-4), 328-340 (doi: 10.1016/j.gloplacha.2006.07.016)

Bai ZG (2009) HJ-1A and HJ-1B small satellite constellation for environment and disaster monitoring. Aerosp. China, 10(2), 2-7

Bai Z and Ohata T (1989) Variations of albedo on the Glacier No. 1 at the headwater of Urumqi river, Tian Shan mountains, during the summer ablation period. J. Glaciol. Geocryol., 11(4), 311-324 [in Chinese with English summary]

Barcaza G, Aniya M, Matsumoto T and Aoki T (2009) Satellitederived equilibrium lines in Northern Patagonia Icefield, Chile, and their implications to glacier variations. Arct. Antarct. Alp. Res., 41(2), 174-182 (doi: 10.1657/1938-4246-41.2.174)

Benn DI and Lehmkuhl F (2000) Mass balance and equilibrium-line altitudes of glaciers in high mountain environments. Quat. Int., 65-66, 15-29 (doi: 10.1016/S1040-6182(99)00034-8)

Bindschadler R, Dowdeswell JA, Hall D and Winther JG (2001) Glaciological applications with Landsat-7 imagery: early assessments. Remote Sens. Environ., 78(1-2), 163-179 (doi: 10.1016/ S0034-4257(01)00257-7)

Bolch T (2007) Climate change and glacier retreat in northern Tien Shan (Kazahkstan/Kyrgyzstan) using remote sensing data. Global Planet. Change, 56(1-2), 1-12 (doi: 10.1016/j.gloplacha.2006. 07.009) 
Bolch T and 11 others (2012) The state and fate of Himalayan glaciers. Science, 336(6079), 310-314 (doi: 10.1126/ science.1215828)

Brown IA, Kirkbride MP and Vaughan RA (1999) Find the firn line! The suitability of ERS-1 and ERS-2 SAR data for the analysis of glacier facies on Icelandic icecaps. Int. J. Remote Sens., 20(15-16), 3217-3230

Casey JA and Kelly REJ (2010) Estimating the equilibrium line of Devon Ice Cap, Nunavut, from RADARSAT-1 ScanSAR wide imagery. Can. J. Remote Sens., 36(S1), S41-S55 (doi: 10.5589/ m10-013)

Chinn TJH (1995) Glacier fluctuations in the Southern Alps of New Zealand determined from snowline elevations. Arct. Alp. Res., 27(2), 187-198

Clare GR, Fitzharris BB, Chinn TJH and Salinger MJ (2002) Interannual variation in end-of-summer snowlines of the Southern Alps of New Zealand, in response to changes in Southern Hemisphere atmospheric circulation and sea surface temperature patterns. Int. J. Climatol., 22(1), 121-128 (doi: 10.1002/ joc.722)

Cogley JG (2009) Geodetic and direct mass-balance measurements: comparison and joint analysis. Ann. Glaciol., 50(50), 96-100 (doi: 10.3189/172756409787769744)

De Ruyter de Wildt MS, Oerlemans J and Björnsson H (2002) A method for monitoring glacier mass balance using satellite albedo measurements: application to Vatnajökull, Iceland. J. Glaciol., 48(161), 267-278 (doi: 10.3189/172756502781831458)

Engeset RV and Weydahl DJ (1998) Analysis of glaciers and geomorphology on Svalbard using multitemporal ERS-1 SAR images. IEEE Trans. Geosci. Remote Sens., 36(6), 1879-1887 (doi: 10.1109/36.729359)

Engeset RV, Kohler J, Melvold K and Lundén B (2002) Change detection and monitoring of glacier mass balance and facies using ERS SAR winter images over Svalbard. Int. J. Remote Sens., 23(10), 2023-2050 (doi: 10.1080/01431160110075550)

Fountain AG, Lewis KJ and Doran PT (1999) Spatial climatic variation and its control on glacier equilibrium line altitude in Taylor Valley, Antarctica. Global Planet. Change, 22(1-4), 1-10 (doi: 10.1016/S0921-8181(99)00020-X)

Gardner AS and 15 others (2013) A reconciled estimate of glacier contributions to sea level rise: 2003 to 2009. Science, 340(6134), 852-857 (doi: 10.1126/science.1234532)

Haeberli W (2004) Glaciers and ice caps: historical background and strategies of worldwide monitoring. In Bamber JL and Payne AJ eds. Mass balance of the cryosphere. Cambridge University Press, Cambridge, 559-578

Hall DK, Williams RS Jr, Barton JS, Smith LC and Garvin JB (2000) Evaluation of remote-sensing techniques to measure decadalscale changes of Hofsjökull ice cap, Iceland. J. Glaciol., 46(154), 375-388 (doi: 10.3189/172756500781833061)

Hock R and Holmgren B (1996) Some aspects of energy balance and ablation of Storglaciären, northern Sweden. Geogr. Ann. A, 78(2-3), 121-131

Hock R and Holmgren B (2005) A distributed surface energybalance model for complex topography and its application to Storglaciären, Sweden. J. Glaciol., 51(172), 25-36 (doi: 10.3189/172756505781829566)

Huang L, Li Z, Tian B, Chen Q and Zhou J (2013) Monitoring glacier zones and snow/firn line changes in the Qinghai-Tibetan Plateau using C-band SAR imagery. Remote Sens. Environ., 137, 17-30 (doi: 10.1016/j.rse.2013.05.016)

Hulth J, Rolstad Denby C and Hock R (2013) Estimating glacier snow accumulation from backward calculation of melt and snowline tracking. Ann. Glaciol., 54(62 Pt 1), 1-7 (doi: 10.3189/ 3013AoG62A083)

Jacob T, Wahr J, Pfeffer WT and Swenson S (2012) Recent contributions of glaciers and ice caps to sea level rise. Nature, 482(7386), 514-518 (doi: 10.1038/nature10847)

Jaenicke J, Mayer C, Scharrer K, Münzer U and Gudmundsson A (2006) The use of remote-sensing data for mass-balance studies at Mýrdalsjökull ice cap, Iceland. J. Glaciol., 52(179), 565-573 (doi: 10.3189/172756506781828340)

Kaser G, Cogley JG, Dyurgerov MB, Meier MF and Ohmura A (2006) Mass balance of glaciers and ice caps: consensus estimates for 1961-2004. Geophys. Res. Lett., 33(19), L19501 (doi: 10.1029/2006GL027511)

Klein AG and Isacks BL (1999) Spectral mixture analysis of Landsat thematic mapper images applied to the detection of the transient snowline on tropical Andean glaciers. Global Planet. Change, 22(1-4), 139-154

König M, Winther JG and Isaksson E (2001) Measuring snow and glacier ice properties from satellite. Rev. Geophys., 39(1), 1-27 (doi: 10.1029/1999RG000076)

Kuhn M (1989) The response of the equilibrium line altitude to climatic fluctuations: theory and observations. In Oerlemans J ed. Glacier fluctuations and climatic change. Kluwer, Dordrecht, 407-417

Kulkarni AV (1992) Mass balance of Himalayan glaciers using AAR and ELA methods. J. Glaciol., 38(128), 101-104

Kutuzov S and Shahgedanova M (2009) Glacier retreat and climatic variability in the eastern Terskey-Alatoo, inner Tien Shan between the middle of the 19th century and beginning of the 21 st century. Global Planet. Change, 69(1-2), 59-70 (doi: 10.1016/j.gloplacha.2009.07.001)

LaChapelle E (1962) Assessing glacier mass budgets by reconnaissance aerial photography. J. Glaciol., 4(33), 290-297

Lamont GN, Chinn TJ and Fitzharris BB (1999) Slopes of glacier ELAs in the Southern Alps of New Zealand in relation to atmospheric circulation patterns. Global Planet. Change, 22(1-4), 209-219 (doi: 10.1016/S0921-8181(99)00038-7)

Li Z (2011) Progress and application of research on Glacier No. 1 at headwaters of Urumqi River, Tianshan, China. China Meteorological Press, Beijing [in Chinese]

Li Z, Han T, Jing Z, Yang H and Jiao K (2003) A summary of 40-year observed variation facts of climate and Glacier No. 1 at headwater of Ürümqi River, Tianshan, China. J. Glaciol. Geocryol., 25(2), 117-123 [in Chinese with English summary]

Lliboutry L (1965) Traité de glaciologie. Tome II: Glaciers, variations du climat, sols gelés. Masson, Paris

Lliboutry L (1998) Glaciers of South America: glaciers of the dry Andes. In Williams RS Jr and Ferrigno JG eds. Satellite image atlas of glaciers of the world. (USGS Professional Paper 1386-I) US Geological Survey, Denver, CO, I119-I147

Narama C, Kääb A, Duishonakunov $M$ and Abdrakhmatov $K$ (2010) Spatial variability of recent glacier area changes in the Tien Shan Mountains, Central Asia, using Corona ( 1970), Landsat ( 2000), and ALOS ( 2007) satellite data. Global Planet. Change, 71(1-2), 42-54 (doi: 10.1016/j.gloplacha. 2009.08.002)

Ohmura A, Kasser P and Funk M (1992) Climate at the equilibrium line of glaciers. J. Glaciol., 38(130), 397-411

Østrem G and Brugman M (1991) Glacier mass-balance measurements: a manual for field and office work. (NHRI Science Report 4) National Hydrology Research Institute, Environment Canada, Saskatoon, Sask.

Parrot JF, Lyberis N, Lefauconnier B and Manby G (1993) SPOT multispectral data and digital terrain model for the analysis of ice-snow fields on arctic glaciers. Int. J. Remote Sens., 14(3), 425-440 (doi: 10.1080/01431169308904348)

Paterson WSB (1994) The physics of glaciers, 3rd edn. Elsevier, Oxford

Paul F, Kääb A and Haeberli W (2007) Recent glacier changes in the Alps observed from satellite: consequences for future monitoring strategies. Clobal Planet. Change, 56(1-2), 111-122 (doi: 10.1016/j.gloplacha.2006.07.007)

Pelto M (2011) Utility of late summer transient snowline migration rate on Taku Glacier, Alaska. Cryosphere, 5(4), 1127-1133 (doi: 10.5194/tc-5-1127-2011)

Pope A and Rees WG (2014a) Impact of spatial, spectral, and radiometric properties of multispectral imagers on glacier 
surface classification. Remote Sens. Environ., 141, 1-13 (doi: 10.1016/j.rse.2013.08.028)

Pope A and Rees G (2014b) Using in situ spectra to explore Landsat classification of glacier surfaces. Int. J. Appl. Earth Obs. Geoinform., 17(A), 42-52 (doi: 10.1016/j.jag.2013.08.007)

Rabatel A, Dedieu J-P and Vincent C (2005) Using remotesensing data to determine equilibrium-line altitude and massbalance time series: validation on three French glaciers, 1994-2002. J. Glaciol., 51(175), 539-546 (doi: 10.3189/ 172756505781829106)

Rabatel A, Dedieu J-P, Thibert E, Letréguilly A and Vincent C (2008) 25 years (1981-2005) of equilibrium-line altitude and massbalance reconstruction on Glacier Blanc, French Alps, using remote-sensing methods and meteorological data. J. Glaciol., 54(185), 307-314 (doi: 10.3189/002214308784886063)

Rabatel A and 7 others (2012) Can the snowline be used as an indicator of the equilibrium line and mass balance for glaciers in the outer tropics? J. Glaciol., 58(212), 1027-1036 (doi: 10.3189/ 2012JoG12J027)

Rabatel A, Letréguilly A, Dedieu J-P and Eckert N (2013) Changes in glacier equilibrium-line altitude in the western Alps from 1984 to 2010: evaluation by remote sensing and modeling of the morpho-topographic and climate controls. Cryosphere, 7(5), 1455-1471 (doi: 10.5194/tc-7-1455-2013)

Racoviteanu AE, Paul F, Raup B, Khalsa SJS and Armstrong R (2009) Challenges and recommendations in mapping of glacier parameters from space: results of the 2008 Global Land Ice Measurements from Space (GLIMS) workshop, Boulder, Colorado, USA. Ann. Glaciol., 50(53), 53-69 (doi: 10.3189/ 172756410790595804)

Shea JM, Menounos B, Moore RD and Tennant C (2013) An approach to derive regional snow lines and glacier mass change from MODIS imagery, western North America. Cryosphere, 7(2), 667-680 (doi: 10.5194/tc-7-667-2013)

Tachikawa T and 12 others (2011) ASTER Global Digital Elevation Model Version 2 - summary of validation results, NASA Land
Processes. NASA Distributed Active Archive Center/Joint Japan-US ASTER Science Team http://www.jspacesystems.or. jp/ersdac/GDEM/ver2Validation/Summary_GDEM2_validation_ report_final.pdf

Wang N, He J, Pu J, Xi J and Jing Z (2010) Variations in equilibrium line altitude of the Qiyi glacier, Qilian mountains, over the past 50 years. Chinese Sci. Bull., 55 (33), 3810-3817 (doi: 10.1007/ s11434-010-4167-3)

Wang P, Li Z and Hi H (2011) Ice volume changes and their characteristics for representative glacier against the background of climatic warming: a case study of Urumqi Glacier No. 1, Tianshan, China. J. Natur. Res., 26(7), 1189-1198 (doi: 10.11849/zrzyxb.2011.07.011)

Wang P, Li Z, Wang W, Li H, Zhou P and Jin S (2013) Changes of six selected glaciers in the Tomor region, Tian Shan, Central Asia, over the past $\sim 50$ years, using high-resolution remote sensing images and field surveying. Quat. Int., 311, 123-131 (doi: 10.1016/j.quaint.2013.04.031)

Wang P, Li Z, Li H, Wang W and Yao H (2014) Comparison of glaciological and geodetic mass balance at Urumqi Glacier No. 1, Tian Shan, Central Asia. Global Planet. Change, 114, 14-22 (doi: 10.1016/j.gloplacha.2014.01.001)

Wang S and 6 others (2011) Response of glacier area variation to climate change in Chinese Tianshan mountains in the past 50 years. Acta Geogr. Sin., 66(1), 38-46 [in Chinese with English summary]

Williams RS Jr, Hall DK and Benson CS (1991) Analysis of glacier facies using satellite techniques. J. Glaciol., 37(125), 120-128

World Glacier Monitoring Service (WGMS) (2012) Fluctuations of glaciers 2005-2010 (Vol. X), ed. Zemp M and 6 others. ICSU/ IUGG/UNEP/UNESCO/WMO, World Glacier Monitoring Service, Zürich

Yao T and 14 others (2012) Different glacier status with atmospheric circulations in Tibetan Plateau and surroundings. Nature Climate Change, 2(7), 663-667 (doi: 10.1038/ nclimate1580) 